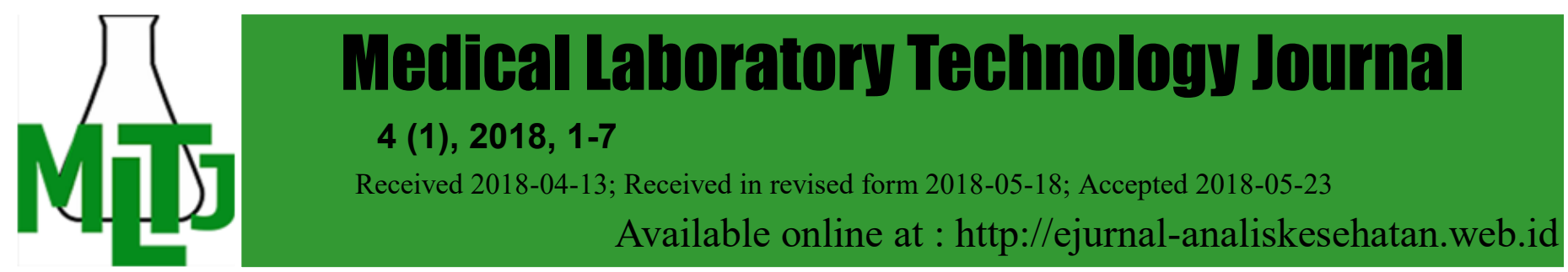

\title{
BLOOD GLUCOSE LEVEL AND Candida spp. GROWTH IN ELDERLY DIABETES MELITUS PATIENTS
}

\author{
Rifqoh, Syaidatul Aslamiyah, Jujuk Anton Cahyono, Erpan Roebiakto \\ Medical Laboratory Technology Poltekkes Kemenkes Banjarmasin \\ Mistar Cokrokusumo Street 4a Banjarbaru, Indonesia. \\ e-mail: rif.mayasin@gmail.com
}

\begin{abstract}
Diabetes mellitus is a presdisposing factor against infection, especially in orofacial area. Infectious diseases are more frequent serious in patients with diabetes mellitus, which potentially increases their morbimortality. The more frequent oral mucosa infection of DM patients is candidiasis which caused by Candida spp. This research is aimed to obtain the correlation between fasting blood glucose level and Candida spp. growth in elderly diabetes mellitus patients. This analytical survey research used cross-sectional design through GOD-PAP methode for fasting blood glucose level test and macroscopic method for total colony of Candida spp. growth. The result of fasting blood glucose level test average $186,06 \mathrm{mg} / \mathrm{dl}$ the highest level is $492,90 \mathrm{mg} / \mathrm{dl}$ and the lowest one is $72,08 \mathrm{mg} / \mathrm{dl}$. Meanwhile, the result of Candida spp. is 131 at the average and the highest growth is 350 and the lowest one is 12 colonies. The result of the research indicates that there is a rising of Candida spp. to level of fasting blood glucose in elderly diabetes mellitus patients. Based on correlational test of spearman, it gains significant value $0,001<\alpha=0,005$ of that shows there is a correlation between fasting blood glucose level and Candida spp. growth in diabetes mellitus elderly patients with the strenght relation $(r)=0,572$ which means in medium level. Further researches about the influence to the other presdisposing factors of Candida spp. growth are recommended .
\end{abstract}

Keywords: diabetes mellitus; glucose level; Candida spp; candidiasis

\section{INTRODUCTION}

Diabetes mellitus (DM) is one of the degenerative diseases that cause serious health problems. Diabetes mellitus is a group of physiological dysfunctions characterized by hyperglycemia resulting directly from insulin resistance, inadequate insulin secretion, or excessive glucagon secretion(Association, 2013; Blair, 2016).

Diabetes caused 1.5 million deaths in 2.1 dleincome countries have the highest propor- Sulawesi $(2.4 \%)$ and East Kalimantan $(2.3 \%)$. tion of deaths attributed to high blood glucose. Diabetes prevalence in South Kalimantan WHO estimates that, globally, 422 million Province is 1\% (range 0,3-1,7\%). Six districts/ adults aged over 18 years were living with dia- cities with prevalence above prevalence rates betes in 2014 more than 400 million people of the provinces is Banjarmasin, Barito Kuala, live with diabetes and 96 million people live Tapin, Banjarbaru, Banjar and Hulu Sungai with diabetes in South-East Asia Region. The Selatan. The prevalence of DM increases in country in Asia Region which have the largest elderly.

numbers of people with diabetes in 2014 is In- dia, China and Indonesia. Diabetes in Indonesia is $5.81 \%$ of the total population and WHO estimates the number increase from 9.1 million in 2014 to 21.3 million in 2030. (Ogurtsova et al., 2017; Organization, 2016)

Indonesia Basic Health Research or RISKESDAS (2013) shows that the proportion of diabetes in Indonesia has increased almost twice compare 2007 from 1.1 percent (2007) to 2.1 percent (2013). The highest diabetes prevalence diagnosed by doctors is found in DI Yogyakarta $(2.6 \%)$, DKI Jakarta $(2.5 \%)$, North Sulawesi $(2.4 \%)$ and East Kalimantan (2.3\%). Tapin, Banjarbaru, Banjar and Hulu Sungai
Selatan. The prevalence of DM increases in 
Diabetes in elderly which generally type 2 $\mathrm{DM}$, encompasses individuals who have insulin resistance, usually have relative insulin deficiency which is probably many different causes. Diabetes and other diseases in elderly patient is a combination of disorders that arise due to disease and aging process. With the increase of the age in elderly, the organ function will have reduced and it could raise various health complaints like Xerostomia. In diabetic patient, xerostomia could caused by the destruction of salivary glands manifests itself with impaired salivary secretion which leads to further damage of oral tissues. Xerostomia manifests subjective symptoms of oral dryness, and hyposalivation can cause a discomfort in the oral cavity. These complaints could arised by bacteri and fungal infection (Malicka et al., 2014; Manurung and Wibisono, 2012).

Candidiasis is fungal infections that more common in diabetic patient, particularly those caused by overgrowth of Candida spp. Oral candidiasis is one of the common fungal infection, affecting the oral mucosa. Its occur due to several factors ie. endocrine diseases such as DM. (Singh et al., 2014)

One case report study reported the polymorphic type of oral candidiasis in the elderly patient which is previously undetected DM. Patient has to wear removable partial dentures and based on clinical examination, oral lesion regarded as oral candidiasis. Those clinical study findings as oral candidiasis can use as an indicator of the existence of the systemic disease, in this case, are DM (Prayudha et al., 2012).

Other study showed that glucose levels affect the occurrence of oral candidiasis in patients with DM (Panchbhai, 2012). Patients who display clinical signs of oral candidiasis have more than $400 \mathrm{CFU} / \mathrm{mL}$. Of Candida spp.p. (Singh et al., 2014). However, in elderly DM patient, many predisposing factors arise Candida spp.p. overgrowth. So, early identification of Candida spp.p. excess needed before oral Candidiasis, and its complications occur. This study obtains the Candida spp.p. growth and its correlation with blood glucose level in elderly Diabetes Mellitus patient.

\section{MATERIAL AND METHODE}

This analytical observational study used the cross-sectional design that obtained fasting blood glucose levels and Candida spp.p growth at one time. Candida spp.p. growth determined by culture method to orofacial swab specimen. Before sampling, subjects were asked to swallow up to reduce saliva on the tongue so that swabs sampling are easy to do. Subjects were asked to open their mouths. Smoothing swab did with sterile lid cotton on the dorsal tongue; then swab is placed in $1 \mathrm{ml}$ $0.9 \% \mathrm{NaCl}$ tube. All swab specimens put into an ice box to the Bacteriology Laboratory.

The cultivation of swabs seed on PDA media by applying swab evenly, then incubated at $37^{\circ}$ C. for 24 hours. The results of Candida spp.p. colonies growth on PDA media observed macroscopically, and the number of colonies counted using Colony counter. If the number of Candida spp.p. colonies growing over 200 colonies calculated by dividing into 4 quadrants and obtained in the first quadrant multiplied by 4 .

The examination of fasting blood glucose used GOD-PAP method. Blood specimen from mediana cubiti venous blood sampling and let the sample frozen in the test tube until serum out, approximately 15 minutes for fresh samples, centrifuged for 10 minutes at $1500 \mathrm{rpm}$ and separated serum from the blood clot. Mix each ten $\mu \mathrm{l}$ serum specimen with $1000 \mu \mathrm{l}$ of glucose reagent and incubated at $20-25^{\circ} \mathrm{C}$ for 10 minutes. This examination used glucose reagent as blank and ten $\mu \mathrm{l}$ glucose standard $100 \mathrm{mg} / \mathrm{dl}$ in $1000 \mu \mathrm{l}$ of glucose reagent as a standard. Absorbance measured with a photometer at $546 \mathrm{~nm}$ wavelength.

\section{RESULTS AND DISCUSSION}

Respondents in this study were patients who had been previously diagnosed diabetes mellitus patients. The characteristics of these respondents by sex, age, last education, and time suffered DM (table 1).

Table 1. Distribution of Respondent Characteristics

\begin{tabular}{lcc}
\hline $\begin{array}{l}\text { Respondent } \\
\text { Characteristics }\end{array}$ & Frequency (N) & Percentage (\%) \\
\hline Sex & & \\
Male & 9 & 29,03 \\
Female & 22 & 70,97 \\
\hline Age & 11 & 35,48 \\
$46-52$ years & 16 & 51,61 \\
$53-62$ years & 4 & 12,91 \\
63-72 years & & \\
Last Education & 9 & 29,03 \\
Elementary school & 4 & 12,90 \\
Junior high school & 10 & 32,26 \\
Senior high school & 8 & 25,81 \\
Diploma 3-University & & \\
Time Suffered DM & 13 & 41,94 \\
$1-5$ years ago & 10 & 19,26 \\
6- 10 years ago & 6 & 6,45 \\
10 - 20 years ago & 2 & \\
$21-31$ years ago & &
\end{tabular}


Based on the respondent characteristics in table 1 shows that female respondent more than men with percentage $70.97 \%$. The dominant respondent's age range 53-62 years with percentage $51.61 \%$. Most of the last education of the respondents are high school graduates with a percentage of $32.26 \%$. Older patients had first diagnosed diabetes from 1 to 5 years with the percentage of $41.94 \%$. While predisposing factors based on drug consumed, smoker, and denture users can be seen in table 2 as follows:

Table 2. Distribution of Predisposing Factors

\begin{tabular}{lcc}
\hline Predisposing Factors & Frequency $(\mathrm{N})$ & Percentage (\%) \\
\hline Drug consumed & 6 & \\
Insulin & 12 & 19,35 \\
Metformin & 10 & 38,70 \\
Glimepiride & 3 & 32,25 \\
Herbal & & 9,68 \\
\hline Smoker & 4 & 12,91 \\
Yes & 27 & 87,09 \\
No & 3 & \\
Denture users & 3 & 9,68 \\
Yes & 28 & 90,32 \\
No & &
\end{tabular}

The average respondent is the type $2 \mathrm{DM}$, as much as $38.70 \%$ of respondents who take metformin drugs, a smoker is $12.91 \%$, and denture users is $9.68 \%$.

\section{Fasting Blood Glucose Level.}

Examination of fasting blood glucose level used GOD-PAP method. Based on the results obtained the average fasting blood glucose level is $186.06 \mathrm{mg} / \mathrm{dl}$. The highest results of blood glucose level are $492.90 \mathrm{mg} / \mathrm{dl}$, and the lowest is $72.08 \mathrm{mg} / \mathrm{dl}$. The number of respondents with fasting blood glucose level above the average is 10 and below average is 21. Results obtained from the examination of blood glucose levels can be seen in table 3 as follows:

Table 3. Results of Fasting Blood Glucose Level Examination

\begin{tabular}{ccc}
\hline $\begin{array}{c}\text { Fasting Blood } \\
\text { Glucose Level }\end{array}$ & Frequency (N) & Percentage (\%) \\
\hline$>186,06 \mathrm{mg} / \mathrm{dl}$ & 10 & 32,25 \\
\hline$<186,06 \mathrm{mg} / \mathrm{dl}$ & 21 & 67,75 \\
\hline
\end{tabular}

\section{Candida spp. Colony Growth.}

Candida spp. colonies data was obtained by examination of Candida spp. culture from mouth swab, then seed on Potato Dextrose agar (PDA) medium and incubated at $37^{\circ} \mathrm{C}$ for 24 hours. The average number of Candida spp. colonies growth which grows on PDA media is 131. While the number of Candida spp. colonies growth as the highest is 350 colonies and the lowest of 12 colonies. For more details the examination results data can be seen in appendix 5 . The number of respondents with the growth of the number of colonies above the average and below average can be seen in table 4 as follows:

\section{Table 4. Percentage of Respondents and Candida spp. Colony Growth}

\begin{tabular}{lcc}
$\begin{array}{l}\text { Number of Candida } \\
\text { spp. Colonies }\end{array}$ & $\begin{array}{c}\text { Frequency } \\
(\mathrm{N})\end{array}$ & $\begin{array}{c}\text { Percentage } \\
(\%)\end{array}$ \\
\hline $\begin{array}{l}\text { Above average of } \\
\text { FBG level Group }\end{array}$ & & \\
\hline $\begin{array}{l}\text { Above average of } \\
\text { Candida spp. } \\
\text { Colonies }\end{array}$ & 8 & 25,81 \\
$\begin{array}{l}\text { Below average of } \\
\text { Candida spp. } \\
\text { Colonies }\end{array}$ & 2 & 6,45 \\
$\begin{array}{l}\text { Below average of } \\
\text { FBG level Group }\end{array}$ & & \\
\hline $\begin{array}{l}\text { Above average of } \\
\text { Candida spp. } \\
\text { Colonies }\end{array}$ & 3 & 9,68 \\
\hline $\begin{array}{l}\text { Below average of } \\
\text { Candida spp. } \\
\text { colonies }\end{array}$ & 18 & 58,07 \\
\hline
\end{tabular}

The number of respondents with fasting blood glucose level above $186.06 \mathrm{mg} / \mathrm{dl}$ is 10 people with the growth of the number of colonies above the average of 8 and below the average 2, while the number of respondents with fasting blood glucose levels under 186, $06 \mathrm{mg} /$ $\mathrm{dl}$ ie 21 with the growth of the number of colonies above the average of 3 and below the average 28

In Table 3 the results were divided into two categories: glucose levels above $186.06 \mathrm{mg} /$ $\mathrm{dl}$ and below $186.06 \mathrm{mg} / \mathrm{dl}$, based on the average value of fasting blood glucose that has been obtained to facilitate the graph of increasing Candida spp. Growth. To see the relationship between blood glucose level with Candida spp. 
Growth can be seen on the graph of elevated
glucose levels above $186,06 \mathrm{mg} / \mathrm{dl}$ with the growth of the number of a colony in picture 1 as follows:

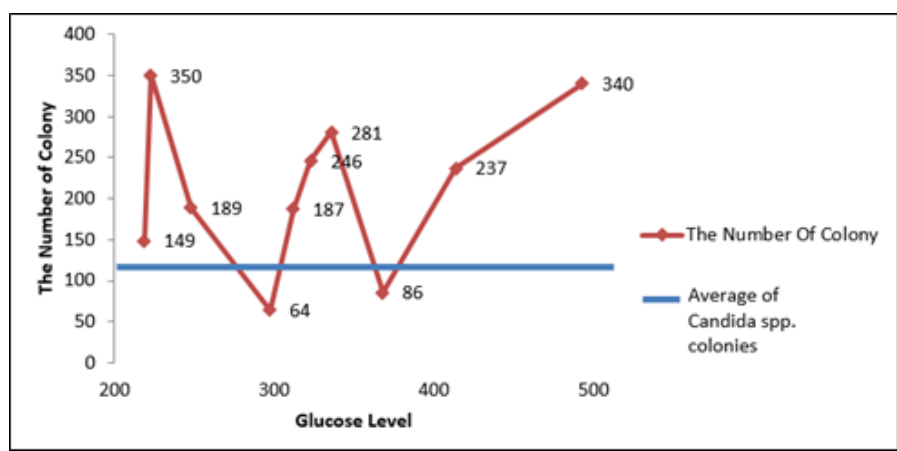

Figure 1. Chart of Number of Candida spp. Colonies in Above Average Blood Glucose Level Group

Based on the above graph the increase of blood glucose level is also followed by the growth of Candida spp. Total colonies because almost all points are above the average line, but there are some points that are still below the average that is the 4th point with the number of colonies only 64 and the point to 8 with the number of colonies is 86 , which can be caused by other factors. While the graph increase the number of colonies with blood glucose levels below $186.06 \mathrm{mg} / \mathrm{dl}$, can be seen in Figure 2 as follows:

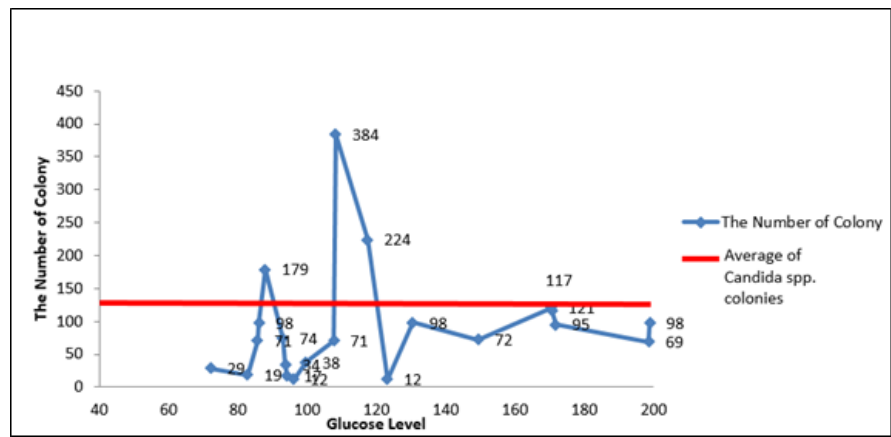

Figure 2. Chart of Number of Candida spp. Colonies in Above Average Blood Glucose Level Group

Based on graph above blood glucose level below 186,06 $\mathrm{mg} / \mathrm{dl}$ also followed by growth of colony amount of Candida spp. because almost all the points are below the average line (straight line), but there are some points that are still above the average line that is the point to 5,12 and 13 with the number of colonies 179, 384, and 224 colonies, which this can be caused by other factors.
Crosstabulation between Respondent Characteristic and Predisposing Factors with Number of Candida spp. Colonies

Crosstabulation between respondent characteristic ie. sex, age, last education and time suffered DM of diabetes with Number of Candida spp. colonies growth can be seen in table 5 as follows:

Table 5. Crosstabulation between Respondent Characteristic with Number of Candida spp. Colonies

\begin{tabular}{|c|c|c|c|c|c|}
\hline \multirow{3}{*}{$\begin{array}{l}\text { Respondent } \\
\text { Characteristic }\end{array}$} & \multirow{3}{*}{$\begin{array}{l}\text { Frequency } \\
\text { (N) }\end{array}$} & \multicolumn{4}{|c|}{ Candida spp. colonies } \\
\hline & & \multicolumn{2}{|c|}{$\leq 131$ colonies } & \multicolumn{2}{|c|}{$>131$ colonies } \\
\hline & & $\mathrm{N}$ & $(\%)$ & $\mathrm{N}$ & $(\%)$ \\
\hline \multicolumn{6}{|l|}{ Sex } \\
\hline Male & 9 & 7 & 22,58 & 2 & 6,45 \\
\hline Female & 22 & 13 & 41,94 & 9 & 29,03 \\
\hline \multicolumn{6}{|l|}{ Age } \\
\hline $46-52$ years & 11 & 6 & 19,35 & 5 & 16,13 \\
\hline $53-62$ years & 16 & 11 & 35,48 & 5 & 16,13 \\
\hline $63-72$ years & 4 & 3 & 9,68 & 1 & 3,23 \\
\hline \multicolumn{6}{|l|}{ Last Education } \\
\hline Elementary school & 9 & 7 & 22,58 & 2 & 6,45 \\
\hline Junior high school & 4 & 4 & 12,90 & 0 & 0,00 \\
\hline Senior high school & 10 & 5 & 16,13 & 5 & 16,13 \\
\hline Diploma 3-University & 8 & 4 & 12,90 & 4 & 12,90 \\
\hline \multicolumn{6}{|l|}{ Time suffered DM } \\
\hline $1-5$ years & 13 & 8 & 25,81 & 5 & 16,13 \\
\hline $6-10$ years & 10 & 7 & 22,58 & 3 & 9,68 \\
\hline $10-20$ years & 6 & 3 & 9,68 & 3 & 9,68 \\
\hline $21-31$ years & 2 & 2 & 6,45 & 0 & 0,00 \\
\hline
\end{tabular}

Crosstabulation between predisposing factors of smoker, denture users, and drug consumed with the number of Candida spp colonies. growth can be seen in table 6 as follows:

Table 6. Crosstabulation between Predisposing Factors with Number of Candida spp. Colonies

\begin{tabular}{|c|c|c|c|c|c|}
\hline \multirow[t]{3}{*}{ Predisposing Factors } & \multirow{3}{*}{$\begin{array}{l}\text { Frequency } \\
\text { (N) }\end{array}$} & \multicolumn{4}{|c|}{ Candida spp. colonies } \\
\hline & & \multicolumn{2}{|c|}{$\leq 131$ colonies } & \multicolumn{2}{|c|}{$>131$ colonies } \\
\hline & & $\mathrm{N}$ & $(\%)$ & $\mathrm{N}$ & $(\%)$ \\
\hline \multicolumn{6}{|l|}{ Smoker } \\
\hline Yes & 4 & 3 & 9,68 & 1 & 3,23 \\
\hline No & 27 & 17 & 54,84 & 10 & 32,26 \\
\hline \multicolumn{6}{|l|}{ Denture users } \\
\hline Yes & 3 & 3 & 9,68 & 0 & 0,00 \\
\hline No & 28 & 17 & 54,84 & 11 & 35,48 \\
\hline \multicolumn{6}{|l|}{ Drugs Users } \\
\hline Insulin & 6 & 4 & 12,90 & 2 & 6,45 \\
\hline Metformin & 12 & 8 & 25,81 & 4 & 12,90 \\
\hline Glimepiride & 10 & 6 & 19,35 & 4 & 12,90 \\
\hline Herbal & 3 & 2 & 6,45 & 1 & 3,23 \\
\hline
\end{tabular}


Crosstabulation between Respondent Characteristic and Predisposing Factors with Fasting Blood Glucose Levels.

Cross tabulation between respondents characteristics such as sex, age, last education time suffered DM of diabetes with fasting blood glucose levels can be seen in table 7 as follows:

Table 7. Cross Tabulation Between Respondents Characteristics With Fasting Blood Glucose Levels

\begin{tabular}{|c|c|c|c|c|c|}
\hline \multirow{3}{*}{$\begin{array}{l}\text { Respondent } \\
\text { Characteristic }\end{array}$} & \multirow{3}{*}{$\begin{array}{l}\text { Frequency } \\
(\mathrm{N})\end{array}$} & \multicolumn{4}{|c|}{ Fasting Blood Glucose Levels } \\
\hline & & \multicolumn{2}{|c|}{$\leq 186,06 \mathrm{mg} / \mathrm{dl}$} & \multicolumn{2}{|c|}{$>186,06 \mathrm{mg} / \mathrm{dl}$} \\
\hline & & $\mathrm{N}$ & $(\%)$ & $\mathrm{N}$ & $(\%)$ \\
\hline \multicolumn{6}{|l|}{ Sex } \\
\hline Male & 9 & 7 & 22,58 & 2 & 6,45 \\
\hline Female & 22 & 13 & 41,94 & 9 & 29,03 \\
\hline \multicolumn{6}{|l|}{ Age } \\
\hline $46-52$ years & 11 & 5 & 16,13 & 6 & 19,35 \\
\hline $53-62$ years & 16 & 11 & 35,48 & 5 & 16,13 \\
\hline $63-72$ years & 4 & 3 & 9,68 & 1 & 3,23 \\
\hline \multicolumn{6}{|l|}{ Last Education } \\
\hline Elementary school & 9 & 7 & 22,58 & 2 & 6,45 \\
\hline Junior high school & 4 & 4 & 12,90 & 0 & 0,00 \\
\hline Senior high school & 10 & 5 & 16,13 & 5 & 16,13 \\
\hline $\begin{array}{l}\text { Diploma } 3 \text { - } \\
\text { University }\end{array}$ & 8 & 4 & 12,90 & 4 & 12,90 \\
\hline \multicolumn{6}{|l|}{ Time suffered DM } \\
\hline $1-5$ years & 13 & 8 & 25,81 & 5 & 16,13 \\
\hline $6-10$ years & 10 & 7 & 22,58 & 3 & 9,68 \\
\hline $10-20$ years & 6 & 3 & 9,68 & 3 & 9,68 \\
\hline $21-31$ years & 2 & 2 & 6,45 & 0 & 0,00 \\
\hline
\end{tabular}

Crosstabulation between predisposing factors of smoker, denture user, and drug user with fasting blood glucose levels can be seen in table 5.8 as follows:

Table 8. Crosstabulation between predisposing factors with fasting blood glucose levels

\begin{tabular}{|c|c|c|c|c|c|}
\hline \multirow{3}{*}{$\begin{array}{l}\text { Fasting Blood } \\
\text { Glucose Levels }\end{array}$} & \multirow{3}{*}{$\begin{array}{l}\text { Frequency } \\
\text { (N) }\end{array}$} & \multicolumn{4}{|c|}{ Fasting Blood Glucose Levels } \\
\hline & & \multicolumn{2}{|c|}{$\leq 186,06 \mathrm{mg} / \mathrm{dl}$} & \multicolumn{2}{|c|}{$>186,06 \mathrm{mg} / \mathrm{dl}$} \\
\hline & & $\mathrm{N}$ & $(\%)$ & $\mathrm{N}$ & $(\%)$ \\
\hline \multicolumn{6}{|l|}{ Smoker } \\
\hline Yes & 27 & 17 & 54,84 & 10 & 32,26 \\
\hline No & 4 & 2 & 6,45 & 2 & 6,45 \\
\hline \multicolumn{6}{|l|}{ Denture Users } \\
\hline Yes & 3 & 2 & 6,45 & 1 & 3,23 \\
\hline No & 28 & 17 & 54,84 & 11 & 35,48 \\
\hline \multicolumn{6}{|l|}{ Drugs Users } \\
\hline Insulin & 6 & 4 & 12,90 & 2 & 6,45 \\
\hline Metformin & 12 & 8 & 25,81 & 4 & 12,90 \\
\hline Glimepiride & 10 & 6 & 19,35 & 4 & 12,90 \\
\hline Herbal & 3 & 2 & 6,45 & 1 & 3,23 \\
\hline
\end{tabular}

Based on the statistical test, the results of Spearman correlation test obtained $p$-value $=$ $0.001(p<0.05)$ which means there is a significant correlation between fasting blood glucose levels with Candida spp. growth in elderly diabetes mellitus patients, with correlation strength $(r)=0,572$. The interval correlation coefficient $(r)=0,40-0,599$ which mean medium level correlation, so the correlation of this study result is in medium level.

Diabetes mellitus is a disease in organs due to reduced insulin produced by pancreatic cells can be absolute or relative. Diabetes mellitus can be bad for all organs and cause various diseases. Diseases that can be caused by diabetes mellitus is an infection of the oral mucosa. One of the disorders that occur in the oral mucosa is oral candidiasis that occurs due to a decreased mucocutaneous barrier and oral immune response to Candida spp. (Casqueiro et al., 2012)

In the patient with diabetes mellitus in the state of hyperglycemia can also cause salivary flow dysfunction, because of the loss of fluid from the body in large quantities, so that the salivary flow is also reduced. Also, hyperglycemia can also result in viscosity of saliva becoming thick and high glucose levels in saliva, that glucose is a good medium for the growth of Candida spp. (Malicka et al., 2014)

Based on Table 3 obtained the average results of glucose blood glucose were 186.06 $\mathrm{mg} / \mathrm{dl}$ and the number of Candida spp. Growth was 131 colonies. The highest blood glucose examination was $492,90 \mathrm{mg} / \mathrm{dl}$, and the lowest was $72,08 \mathrm{mg} / \mathrm{dl}$ (Table 4). Meanwhile, the number of Candida spp. Growth as the highest 350 colonies and the lowest is 12 colonies. Based on the average glucose content obtained, the data were divided into two categories, above average glucose level group (figure 1) and below average glucose level group (figure 2), to facilitate the graph of the increase in the growth of Candida spp. Colonies. The number of respondents whose blood glucose levels were higher than 186,06 $\mathrm{mg} / \mathrm{dl}$, ie 10 with the growth of colonies above the average of 8 and below the average of 2 persons, while the number of respondents whose blood glucose levels were lower than 186, $06 \mathrm{mg} / \mathrm{dl}$ ie 21 people with the growth of colonies above the average of 3 people and below the average of 28 people. 
Based on Figure 1 and 2 , there is a growth of Candida spp. Colonies in the oral smears, of which the highest blood glucose level is $492.90 \mathrm{mg} / \mathrm{dl}$ with the number of Candida spp. Colon is 340 , whereas at the lowest blood glucose level is $72.08 \mathrm{mg} / \mathrm{dl}$ with the number of colonies as many as 29 . In the data have obtained results where the respondents whose blood glucose levels above $186.06 \mathrm{mg} / \mathrm{dl}$ above average colony growth of 8 people more than the below average. This means that the increased glucose levels increase Candida spp. Growth.

Figure 1 shows elevated blood glucose levels above $186.06 \mathrm{mg} / \mathrm{dl}$ followed by the number of Candida spp. Colonies growth as almost all points is above the mean line, whereas in Figure 2 also shows be seen that increased blood glucose level which below $186.06 \mathrm{mg} / \mathrm{dl}$ is also followed by the number of Candida spp. Colonies growth as almost all points is below the average line, although not as much as the growth of colonies in levels above $186.06 \mathrm{mg} / \mathrm{dl}$. This study is by previous research (Zomorodian et al., 2016) which states the factors that affect the increased susceptibility of DM patients to candidiasis is high blood glucose levels (hyperglycemia). The results of the study also mentioned there is a significant relationship between blood glucose levels and the growth of Candida spp. in unregulated diabetes mellitus; it means that high blood glucose levels and uncontrolled affect the incidence of Candida spp. Infection.

Based on the study (Sumintarti and Rahman, 2015) on the correlation of salivary glucose levels with blood glucose to oral candidiasis in patients with diabetes mellitus, it concluded that high salivary glucose levels followed by high blood glucose levels. Increased levels of glucose affect the occurrence of oral candidiasis in DM patients. Glucose is a good medium for the growth of microorganisms including Candida spp.

Figure 1 at point 4th and 8th with the number of Candida spp. are 64 and 86 colonies its mean the number below the average of Candida spp. Colonies growth but its have high glucose level and Figure 2 at the 5th, 12th and 13th points with 179, 384 and 224 colonies, its found increasing number of Candida spp. Colonies growth but its have normal glucose. This is not in line with the statement due to several factors. Many factors could in- fluence the differences in the number of Candida spp. Colonies growth each sample that is, blood glucose levels in patients, smoker, denture users and drugs users.

The correlation between respondent characteristics and predisposing factors with the number of Candida spp. Colonies show no results could affect Candida spp. Colonies growth, because the results show that colonies growth is below the average numbers of colonies growth. Meanwhile, crosstabulation results between respondent characteristics with fasting blood glucose level that in respondents at age 46-52 years is six respondent $(19.35 \%)$, it was the most age group whose glucose level above the average value. Its caused by in orderly DM patient aged $\geq 45$ years has an increased risk of developing diabetes mellitus and glucose intolerance. An increased risk is due to degenerative factors that decrease the body's function to metabolize glucose.(Casqueiro et al., 2012; Organization, 2016)

The risk of developing glucose intolerance increases with age. In elderly DM patients, especially in the case of uncontrolled hyperglycemia, its cause the destruction of salivary glands followed by impaired salivary secretion and may cause xerostomia or oral dryness which leads to further oral lesions. Impaired salivary secretion may increase glucose concentration in saliva which leads to Candida spp. Colonies growth because glucose is an important fuel source to support Candida spp. living organisms (Malicka et al., 2014; Ng et al., 2016)

\section{CONCLUSION}

There is a significant correlation between fasting blood glucose level with Candida spp. Growth in elderly diabetes mellitus patients.

\section{REFERENCES}

American Diabetes Association, (2013). Diagnosis and classification of diabetes mellitus. Diabetes Care. 36(S67-S74).

Blair, M. (2016). Diabetes Mellitus Review. Urol. Nurs., 36.

Casqueiro, J., Casqueiro, J., Alves, C., (2012). Infections in patients with diabetes mellitus: A review of pathogenesis. Indian J. Endocrinol. Metab. 16(S27). 
Malicka, B., Kaczmarek, U., SkośkiewiczMalinowska, K., (2014). Prevalence of xerostomia and the salivary flow rate in diabetic patients. Adv Clin Exp Med. 23 (225-33).

Manurung, A.K.W., Wibisono, G., (2012). Pengaruh xerostomia terhadap kesehatan gigi dan mulut terkait kualitas hidup pada usila. Fakultas Kedokteran.

Shan Ng, T., Desa, M.N.M., Sandai, D., Chong, P.P., Than, L.T.L., (2016). Growth, biofilm formation, antifungal susceptibility and oxidative stress resistance of Candida glabrata are affected by different glucose concentrations. Infect. Genet. Evol. 40(331-338).

Ogurtsova, K., da Rocha Fernandes, J.D., Huang, Y., Linnenkamp, U., Guariguata, L., Cho, N.H., Cavan, D., Shaw, J.E., Makaroff, L.E., (2017). IDF Diabetes Atlas: Global estimates for the prevalence of diabetes for 2015 and 2040. Diabetes Res. Clin. Pract. 128(40-50).

World Health Organization, (2016). Global report on diabetes.

Panchbhai, A.S., (2012). Correlation of salivary glucose level with blood glucose level in diabetes mellitus. J. Oral Maxillofac. Res. 3.

Prayudha, S.A.E., Chrismawaty, B.E., Agustina, D., Subagyo, G., (2012). Kandisiasis Mulut sebagai Indikator Penyakit Sistemik. Maj. Kedokt. Gigi Indones. 19 (162-166).

RISKESDAS oleh Badan penelitian dan pengembangan kesehatan kementerian kesehatan RI, (2013). Riset Kesehatan Dasar. Jakarta

Singh, A., Verma, R., Murari, A., Agrawal, A., (2014). Oral candidiasis: An overview. J. Oral Maxillofac. Pathol. JOMFP. 18 (S81).

Sumintarti, S., Rahman, F., (2015). Korelasi kadar glukosa saliva dengan kadar glukosa darah terhadap terjadinya kandidiasis oral pada penderita diabetes melitus (Correlation of salivary glucose level and blood glucose level with oral candidiasis in diabetes mellitus patient). $J$. Dentomaxillofacial Sci. 14(29-31).

Zomorodian, K., Kavoosi, F., Pishdad, G.R., Mehriar, P., Ebrahimi, H., Bandegani, A., Pakshir, K., (2016). Prevalence of oral Candida colonization in patients with diabetes mellitus. J. Mycol. Medicale. 26(103-110) 